\title{
INFLUENCE OF ACETYLSALICYLIC ACID ON HEMATOTOXICITY OF BENZENE
}

\author{
JOANNA KOWALÓWKA-ZAWIEJA, BARBARA ZIELIŃSKA-PSUJA, \\ JĘDRZEJ PRZYSTANOWICZ, and KARINA SOMMERFELD
}

\author{
Poznan University of Medical Sciences, Poznań, Poland \\ Department of Toxicology
}

\begin{abstract}
Objectives: The aim of the study was to evaluate the influence of acetylsalicylic acid (ASA) on benzene hematotoxicity in rats. Materials and Methods: The study was carried out on rats exposed for 2, 4 and 8 weeks to benzene vapour at a concentration of 1.5 or $4.5 \mathrm{mmol} / \mathrm{m}^{3}$ of air (5 days per week, 6 hours per day) alone or together with ASA at the doses of 5,150 or $300 \mathrm{mg} / \mathrm{kg}$ body weight (per os). Results: Benzene at a concentration of $4.5 \mathrm{mmol} / \mathrm{m}^{3}$ caused a slight lymphopenia, granulocytosis and reticulocytosis in blood. In bone marrow traits of megaloblastic renewal, presence of undifferentiated cells and giant forms of granulocytes as well as an increase in myeloperoxidase and decrease in chloroacetate esterase activity and lipids content were noted. ASA (150 and $300 \mathrm{mg} / \mathrm{kg}$ b.w.) influenced some of hematological parameters, altered by benzene intoxication. ASA limited the solvent-induced alteration in blood reticulocyte count and in the case of bone marrow in the erythroblasts count. Traits of megaloblastic renewal in bone marrow were less pronounced. Besides, higher activity of myeloperoxidase and the decrease in the level of lipids in granulocytes were noted. Conclusion: Our results suggest that ASA limited the benzene-induced hematotoxicity.
\end{abstract}

Key words:

Benzene, Acetylsalicylic acid, Interactions, Hematotoxicity, Blood, Bone marrow

\section{INTRODUCTION}

Occupational exposure to benzene is a frequent cause of chronic toxicity, which may result in induction of aplastic anemia and neoplastic processes, including leukemias, as well as breast and lung tumors. Proliferative disorders of the hemopoietic system, which most frequently develop in humans exposed to benzene, include chronic myeloid leukemia, acute myeloid leukemia, lymphoblastic leukemia, malignant lymphoma and multiple myeloma. Development of tumors of the hemopoietic system reflects the damage to bone marrow pluripotential stem cells, which leads to anemia, leukopenia or thrombocytopenia and, then, to fully symptomatic aplastic anemia or myeloid leukemia [1,2].
The mechanism of benzene hematotoxicity is not clear yet. One theory stresses the importance of active benzene metabolites and cellular DNA adducts, particularly inherited in somatic cell lines, which cause inability of the cells to react to cytokines, resulting in excessive proliferation. Chromosomal aberrations induced by binding active benzene metabolites to DNA may also lead to oncogenes activation or antioncogenes inactivation [3-5].

Another hypothesis is associated with stimulatory functions of the bone marrow microenvironment. Cytotoxic damage of bone marrow stromal cells and macrophages, in particular induced by benzene and its metabolites, affects their capacity to control proliferation and differentiation

Received: January 29, 2013. Accepted: September 5, 2013.

Corresponding author: J. Kowalówka-Zawieja, Department of Toxicology, Poznan University of Medical Sciences, Dojazd 30, 60-631 Poznań, Poland (e-mail: jzawieja@ump.edu.pl). 
of stem cells. Failure to synthesize normal signaling polypeptides results in uncontrolled proliferation of cells which would otherwise be inhibited or the cells would be forced to differentiate into individual cell lines. In a similar way, a disturbed immune system including lymphocytes and stromal macrophages may also lead to development of neoplastic cells, which in physiological conditions would be detected and selected out by the immune surveillance mechanisms [6-10].

Hematotoxic activity of benzene involves both, the solvent and its metabolites. Induction of the cytochrome P-450 system, especially CYP 2E1 and CYP 2B1, which participates in metabolic activation of benzene, may lead to intensification of the observed alterations [11-13]. It has been demonstrated that acetylsalicylic acid (ASA), a widely used non-steroid anti-inflammatory drug, induces cytochrome P-450. Therefore, its prolonged administration for the purpose of prevention of cardiac and cerebral infarcts may lead to metabolic interactions with other xenobiotics, including benzene [14-16].

ASA may also modify toxic effects of benzene by inhibition of transcription factor $\mathrm{\kappa B}$, which participates in activation of genes involved in synthesis of inflammatory factors as well as being responsible for proliferation and maturation of T lymphocytes [17,18]. Hydroquinone, a benzene metabolite, exhibits a similar activity - it inhibits transcription and translocation of the $\mathrm{\kappa B}$ factor to the cell nucleus by suppression of the translocation pathway composed of protein kinase $\mathrm{B}(\mathrm{Akt})$, kinase $\mathrm{I} \kappa \mathrm{B} \beta(\mathrm{IKK} \beta)$ and inhibitor $\alpha$ of $\kappa \mathrm{B}$ protein $(\mathrm{I} \kappa \mathrm{B} \alpha)[10,19,20]$.

Secondary activation of benzene metabolites in bone marrow to the highly reactive compounds is paralleled by formation of free radicals and is responsible for cell membrane damage and genotoxicity [3,5,21]. ASA-induced inhibition of prostaglandin G2 transformations, resulting from repression of endogenous synthase, may lower activity of macrophage peroxidase and, thus, the capacity to form active metabolites [22-24].
ASA inhibits inflammatory processes by prostaglandin and nitric oxide production, which may result in reduction of hematotoxic effects of benzene [17,22,25].

The aim of our study was to investigate the effect of oral acetylsalicylic acid administration on hematotoxicity of benzene after inhalation exposure.

\section{MATERIALS AND METHODS}

\section{Animals}

The studies were performed on male Wistar rats. The animals originated from the breeding farm of the Department of Toxicology, Poznan University of Medical Sciences. The body weight of each rat was $230 \pm 15 \mathrm{~g}$. The rats were housed in controlled light conditions (12 h light : $12 \mathrm{~h}$ dark), at $22^{\circ} \mathrm{C}$ and relative humidity of $60 \pm 10 \%$. The animals were fed with standard laboratory chow with free access to tap water.

\section{Treatment protocols}

The animals were subjected to inhalatory exposure to benzene (Sigma-Aldrich) vapour at a concentration of $1.5 \mathrm{mmol} / \mathrm{m}^{3}$ (37 ppm) or $4.5 \mathrm{mmol} / \mathrm{m}^{3}$ (112 ppm). The exposure took place in a dynamic toxicological chamber for 5 days a week, $6 \mathrm{~h}$ every day, for a period of 2, 4 or 8 weeks. Concentration of the solvent inside the toxicological chamber was monitored by gas chromatographic analysis of air samples with 30 min intervals (packed column Supelco: 5\% DIDP/ 5\% Bentone 34 on $80 / 100$ Chromosorb W NAW, 6' $\times 1 / 8$ " SS, column temperature $80^{\circ} \mathrm{C}$, carrier gas flow $20 \mathrm{~cm}^{3} / \mathrm{min}$, FID detector, sample volume $10 \mathrm{~cm}^{3}$ ). Before each exposure, the rats received an aqueous suspension of ASA (Sigma-Aldrich) administered p.o. at a dose of $5 \mathrm{mg} / \mathrm{kg}$ b.w. $\left(1 / 300 \mathrm{DL}_{50}\right)$ or $150 \mathrm{mg} / \mathrm{kg}$ b.w. $\left(1 / 10 \mathrm{DL}_{50}\right)$ or $300 \mathrm{mg} / \mathrm{kg}$ b.w. $\left(1 / 5 \mathrm{DL}_{50}\right)$. On the 3rd day after exposure cycle termination, blood was sampled from the heart of superficially anesthetized rats. In the blood, hemoglobin concentration, hematocrit 
value and number of reticulocytes (Ret) and leukocytes were established. Peripheral blood and bone marrow smears were evaluated after staining by the use of the May-Grünwald-Giemza (MGG) technique. Leukocyte alkaline phosphatase (LAP) activity in the smears of blood and the activity of acid phosphatase (ACP), myeloperoxidase (MPO), naphthol AS-D chloroacetate esterase (CAE), $\alpha$-naphthyl acetate esterase (ANAE) and the content of lipids (reaction with Sudan Black B), and mucopolysaccharides (PAS reaction) were evaluated in smears of the bone marrow using standard methods described in Wintrobe's Clinical Hematology 11th Ed [26]. Assessment of reactions for LAP, ACP, MPO, CAE and reactions with Sudan Black B involved a semi-quantitative technique, i.e. 100 granulocytes were counted, classifying the enzyme activity in every cell on a 5 -grade scale:

- 0 - negative reaction,

- I - weakly positive reaction,

- II - positive reaction (numerous fine or single coarse granules),

- III - positive reaction (numerous coarse granules),

- IV - strongly positive reaction (coarse granules filling the whole cell).

The results were given in the score representing the sum of products of granulocyte count and the number of a given class. Activities of $\alpha$-naphthyl acetate esterase and mucopolysaccharide content were expressed as the percentage of cells with a positive reaction. All experimental procedures were approved by the Local Ethical Committee for Experiments on Animals (3/2004).

\section{Statistical analysis}

When normal distribution of the experimental data was established using the Kolmogorov test, significant differences $(p<0.05)$ between experimental groups were evaluated using ANOVA-test. If ANOVA detected significant differences $(p<0.05)$, Dunnett's test was used to compare the experimental groups to the control groups. Time impact on inter-group differences was tested by the use of the interactive Tukey's test. The results of blood and bone marrow smears, which did not follow normal distribution, were tested using the non-parametric Kruskal-Wallis or Mann-Whitney U tests.

\section{RESULTS}

\section{Red blood cell system}

Hemoglobin concentration

Two weeks of exposure to benzene at concentrations of $1.5 \mathrm{mmol} / \mathrm{m}^{3}$ and $4.5 \mathrm{mmol} / \mathrm{m}^{3}$ decreased or increased blood hemoglobin level by about $11 \%$, respectively (Table 1). In the rats, which were subjected to 4 and 8 week exposure to benzene, hemoglobin level resembled that noted in the control group. In the rats treated with the highest dose of ASA (300 mg $/ \mathrm{kg}$ b.w.) for 2 weeks, blood hemoglobin concentration was elevated (by about 16\%). No effect of the lower doses of ASA was detected. Parallel exposure to both xenobiotics did not affect hemoglobin levels.

\section{Hematocrit}

Benzene and ASA did not change hematocrit value, irrespective of the type and duration of the experiment.

\section{Reticulocyte count}

Blood reticulocyte number was increased after 2 weeks of inhalatory exposure to benzene at a concentration of $4.5 \mathrm{mmol} / \mathrm{m}^{3}$ and reached a maximum (around 98\%o) after 4 weeks of exposure (Table 1). In the same period, elevated Ret levels were also noted in the group of animals exposed to lower concentrations of the solvent. None of the examined ASA doses affected Ret levels. However, in the rats exposed to benzene and ASA for the period of 4 weeks, Ret level was lower than in the rats exposed to benzene alone. After 8 weeks of exposure, Ret levels in all experimental groups resembled the level determined in the control group. 

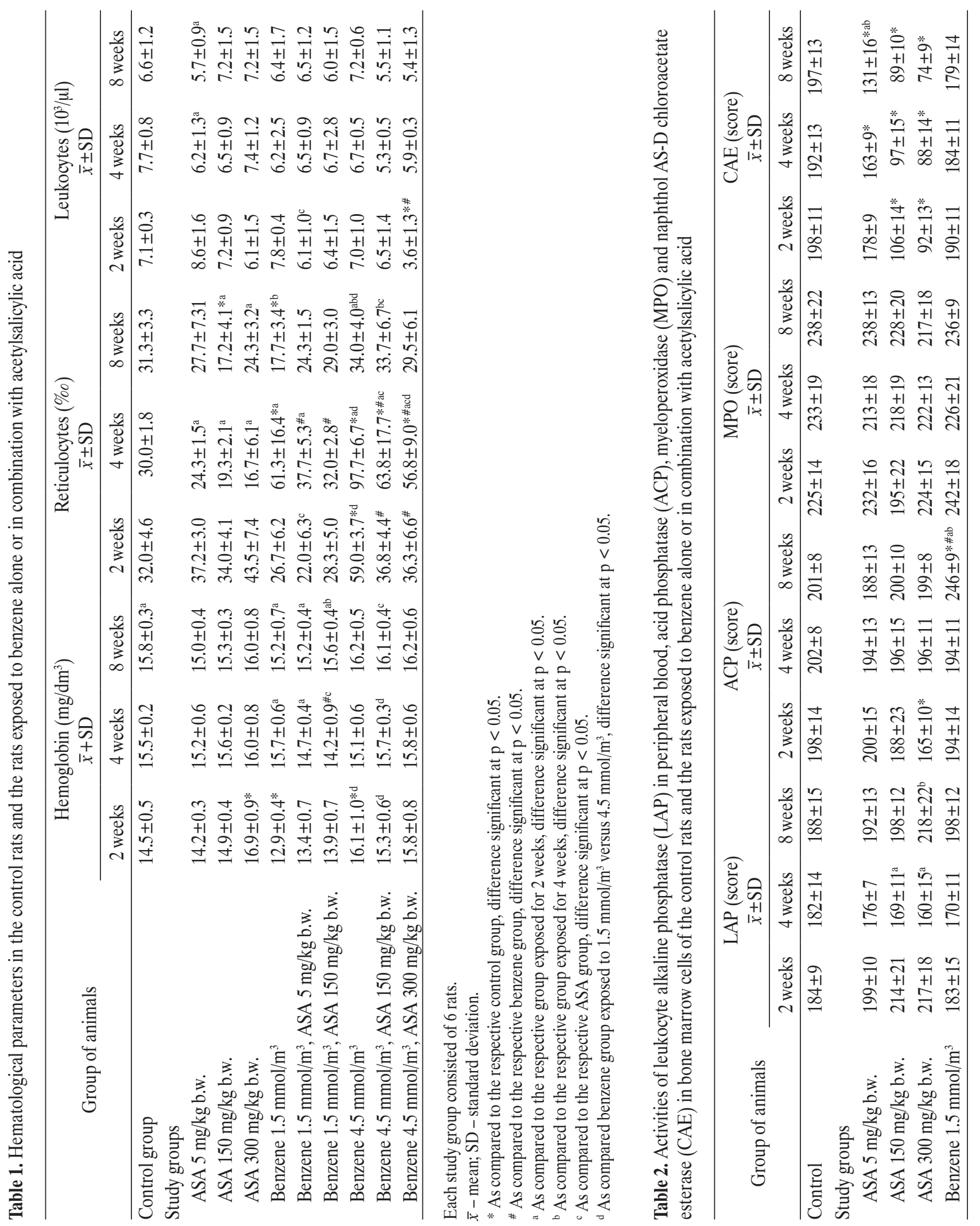


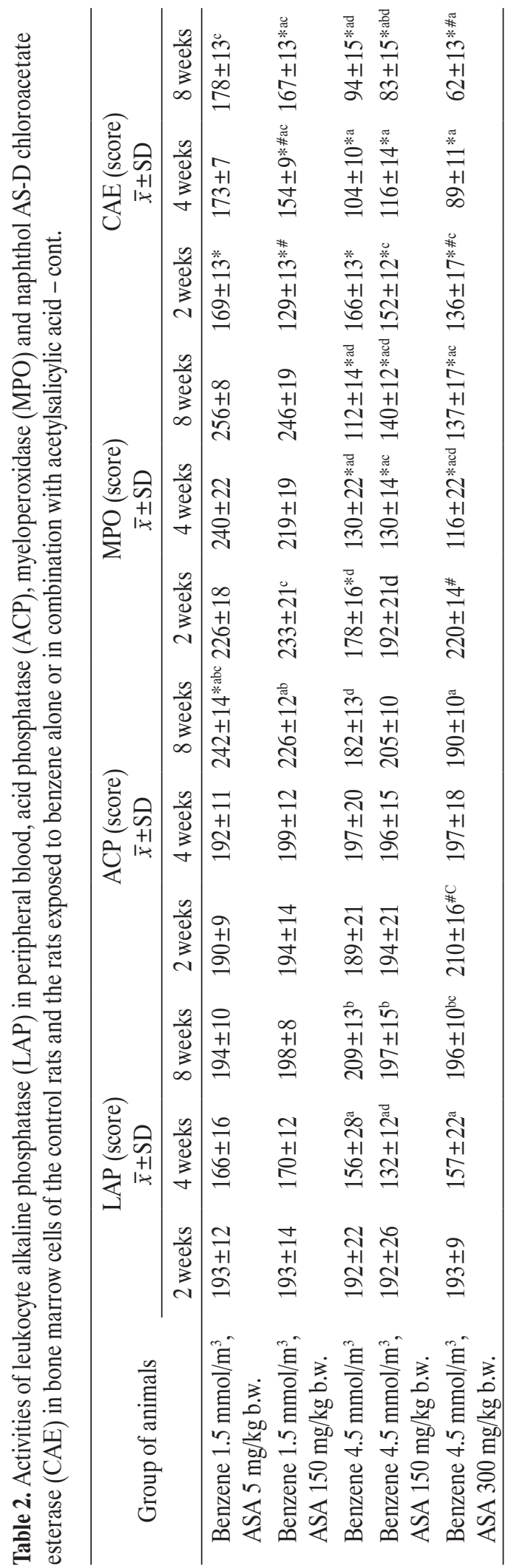

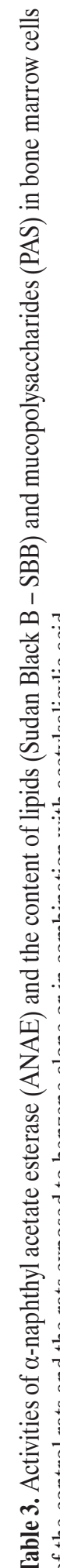

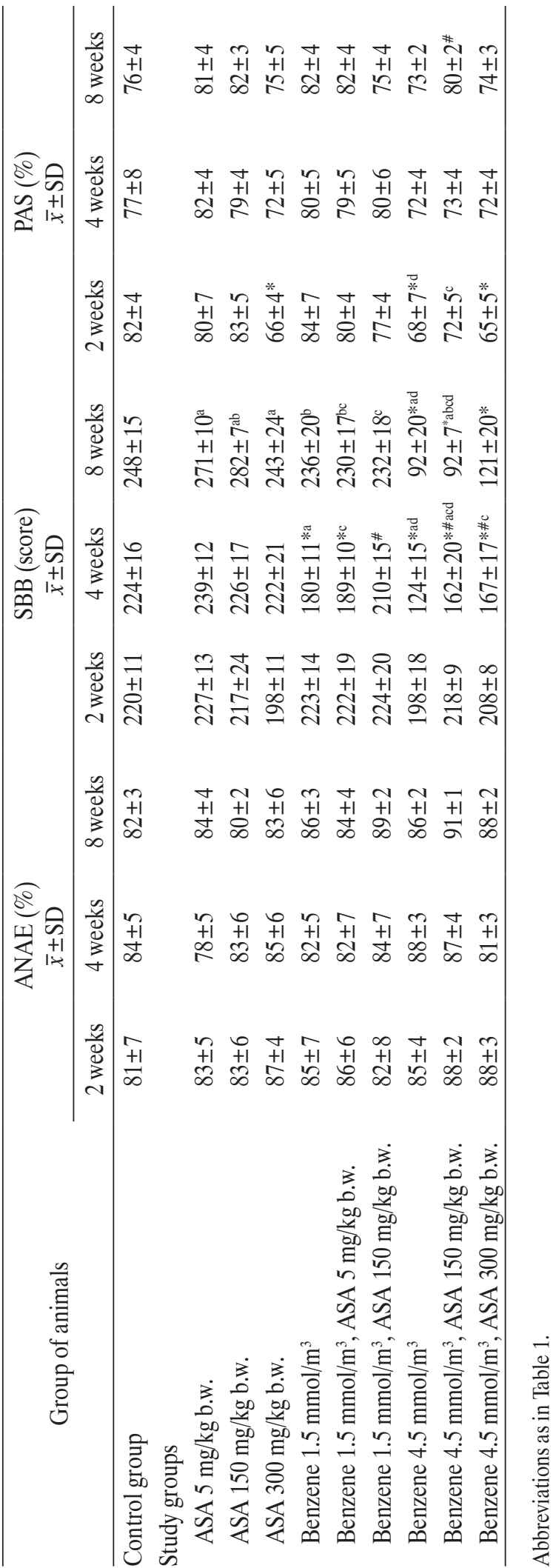


Morphology of peripheral erythrocytes

In the rats, which were exposed to benzene, slight hypochromia, polychromatophilia and slight anisocytosis with the prevalence of microcyte population were observed. The alterations became more pronounced along with increasing concentration of the solvent and with increasing exposure duration. In blood smears of the rats exposed to benzene at a concentration of $4.5 \mathrm{mmol} / \mathrm{m}^{3}$ for 4 or 8 weeks, presence of individual erythroblasts was noted. In the animals that were given ASA alone, the smears of peripheral blood did not show alterations in erythrocyte morphology. Changes induced by benzene exposure were less pronounced after simultaneous exposure to both xenobiotics.

Bone marrow erythroid cells

Benzene exposure at $4.5 \mathrm{mmol} / \mathrm{m}^{3}$ increased the content of cells of the erythroid system in bone marrow. Traits of megaloblastic renewal appeared in the 4 th $\left(4.5 \mathrm{mmol} / \mathrm{m}^{3}\right)$ or in the 8 th week $\left(1.5 \mathrm{mmol} / \mathrm{m}^{3}\right)$ of exposure. Similarly, the number of cells in karyokinesis was increased, depending on duration of the experiment and concentration of the solvent. As compared to the animals exposed exclusively to benzene, the animals exposed in parallel to the solvent and ASA manifested a reduced number of cells in karyokinesis and less pronounced signs of megaloblastic renewal.

\section{White blood cells}

Blood leukocytes

Blood leukocyte number was decreased by around $49 \%$ only in the group of rats exposed for 2 weeks to benzene at a concentration of $4.5 \mathrm{mmol} / \mathrm{m}^{3}$ and administered with ASA at a dose of $300 \mathrm{mg} / \mathrm{kg}$ b.w. (Table 1). In other experimental groups, leukocyte count varied, but the observed differences proved insignificant.

After exposure to any of the two concentrations of benzene, disturbances in the white blood cell pattern were detected, including an augmented proportion of neutrophilic granulocytes and a lowered content of lymphocytes. The alterations became more pronounced along with increasing duration of exposure. Moreover, exposure to a higher concentration of benzene induced the occurrence of undifferentiated cells. ASA at a dose of $300 \mathrm{mg} / \mathrm{kg}$ b.w. increased a proportion of neutrophilic and acidophilic granulocytes, and the occurrence of individual cells of altered morphology was noted. Lower doses of the drug failed to affect proportions of the white blood cell types. In the animals exposed to both xenobiotics in parallel, lymphopenia and granulocytosis were manifested but the alterations did not reach significant levels.

\section{Bone marrow myeloid cells}

In none of the experimental groups significant changes in bone marrow cell content were detected. The evaluated smears were rich in cells.

Giant forms of granulocytes were detected after 4 or 8 weeks of benzene exposure at $1.5 \mathrm{mmol} / \mathrm{m}^{3}$ and after 2,4 or 8 weeks of exposure to benzene at $4.5 \mathrm{mmol} / \mathrm{m}^{3}$. In the rats exposed to the higher concentration of benzene, undifferentiated cells were present. Simultaneous administration of ASA (150 or $300 \mathrm{mg} / \mathrm{kg}$ b.w.) and benzene $\left(4.5 \mathrm{mmol} / \mathrm{m}^{3}\right)$ slightly elevated the content of granulocytes. As compared to the rats exposed to benzene alone, the rats given both xenobiotics in parallel manifested lower numbers of giant cells.

\section{Cytochemical stains}

Changes in LAP, ACP, ANAE activities and in mucopolysaccharide content observed in the animals treated with benzene and acetylsalicylic acid alone or in combination were nonspecific (Tables 2 and 3 ).

Activity of myeloperoxidase

Benzene at a concentration of $4.5 \mathrm{mmol} / \mathrm{m}^{3}$ inhibited MPO activity by $21 \%, 44 \%$ and $53 \%$, after 2,4 and 8 weeks 
of exposure, respectively (Table 2). ASA in any dose and any studied period did not significantly influence MPO activity. Simultaneous exposure to ASA (150 or $300 \mathrm{mg} / \mathrm{kg}$ b.w.) and benzene $\left(4.5 \mathrm{mmol} / \mathrm{m}^{3}\right)$ for 2 weeks increased MPO activity to the values observed in the control group. After prolonging the exposure period to 4 or 8 weeks, the protective effect of the drug was not found.

Activity of naphthol AS-D chloroacetate esterase Inhibition of CAE was observed in the animals exposed to benzene vapour at a concentration of $4.5 \mathrm{mmol} / \mathrm{m}^{3}$ by about 16, 46 and $52 \%$ after 2, 4 and 8 weeks, respectively (Table 2). In the case of each ASA dose activity of CAE was decreased. ASA at doses of 150 and $300 \mathrm{mg} / \mathrm{kg}$ b.w. decreased CAE activity after 2, 4 and 8 weeks of administration by about $46 \%$ and $54 \%, 49 \%$ and $54 \%$, and $55 \%$ and $62 \%$, respectively. A similar effect was observed in the rats treated with the lowest ASA dose $(5 \mathrm{mg} / \mathrm{kg}$ b.w.) for 4 and 8 weeks. Both xenobiotics caused a decrease in CAE activity in all experimental groups.

\section{Content of lipids}

Exposure to the highest concentration of benzene (4.5 $\mathrm{mmol} / \mathrm{m}^{3}$ ) decreased the content of lipids after 4 and 8 weeks by about $45 \%$ and $63 \%$, respectively (Table 3). Simultaneous administration of ASA at any tested dose caused a slight increase in the content of lipids which was less pronounced only after exposure to the solvent.

\section{DISCUSSION}

Toxic activity of benzene may lead to functional disturbances in stem cells and, in effect, to cytopenia (aplastic anemia) or excessive proliferation (leukemia). In humans, decreased levels of hemoglobin and erythrocyte number as well as an altered count of reticulocytes represent the first alterations indicating chronic intoxication with benzene. Furthermore, exposure to the solvent was followed by morphological alterations in the form of toxic granules, traits of degeneration in the cytoplasm and in the cell nucleus [2,27].

In our studies we have detected no significant effects of benzene on the level of hemoglobin and the value of hematocrit, but in smears of peripheral blood we have noticed slight hypochromia, polychromatophilia, poikilocytosis and microcytosis. The alterations have been intensified by prolongation of exposure time, which is connected with the release of less mature erythrocytes from bone marrow to the blood. In our study high reticulocytosis was noted after 2 weeks or 4 weeks of exposure to the solvent alone. However, after 8 weeks a lowered reticulocyte content and occurrence of traits of megaloblastic renewal were observed. It may be connected with depletion of compensatory capacities of bone marrow because of the fact that occurrence of erythroblasts in the rats' blood was noted. Parallel administration of acetylsalicylic acid has significantly reduced the benzene-induced elevated content of reticulocytes.

Administration of ASA together with benzene has resulted in lower numbers of blood reticulocytes and bone marrow erythroblasts. It may be associated with the influence of ASA on benzene biotransformation to phenol which was shown in our previous study [16]. Phenol, one of benzene metabolites, undergoes secondary bioactivation in bone marrow, so its lowered concentration may limit benzene toxicity to the erythroid system.

Additionally, ASA-inhibited metabolism of arachidonic acid and free radical formation can counteract the bone marrow stromal cells damage caused by benzene. Occurrence of benzene myelotoxicity was prevented by simultaneous administration to mice of indomethacin $(2 \mathrm{mg} / \mathrm{kg}$ b.w. i.p. $)$ or aspirin $(50 \mathrm{mg} / \mathrm{kg}$ b.w. i.p. $)$ or meclofenamate (4 $\mathrm{mg} / \mathrm{kg}$ b.w. i.p.) [22].

In our studies, the decreased number of leukocytes has been detected only in the group of animals exposed for 2 weeks to benzene at a concentration of $4.5 \mathrm{mmol} / \mathrm{m}^{3}$ 
and ASA at a dose of $300 \mathrm{mg} / \mathrm{kg}$ b.w. In other experimental groups the unchanged levels of leukocytes were noted. Analysis of blood smears has revealed an increased content of neutrophilic granulocytes, which has been accentuated by exposure prolongation. Changes in the number of neutrophilic granulocytes have been accompanied by structural disturbances, involving cell nuclei, presence of toxic granules as well as traits of cytoplasmic degeneration. Granulocytosis was observed in the rats exposed to benzene ( $300 \mathrm{ppm}$ ) for 13 weeks and in the mice exposed to benzene (100 and $300 \mathrm{ppm}$ for the entire lifetime), and they related it to the intensified proliferation of promyelocytes and myelocytes [28,29].

In contrast, Hazel et al. [30] suggested that hydroquinone created in benzene biotransformation inhibited differentiation of bone marrow granulocytes at the stage of myelocytes. ASA itself at a dose of $300 \mathrm{mg} / \mathrm{kg}$ b.w. increased the content of both neutrophilic and acidophilic granulocytes. However, in the rats exposed simultaneously to benzene and ASA no intensification of granulopoiesis was noted. It may have been expected due to the combination of the effects of both compounds and a distinct target of each of them: benzene is responsible mainly for the damage of precursor cells, while ASA modifies functions of cytokines. In our studies, we have detected lymphopenia which has been intensified by prolongation of exposure to benzene. Studies with benzene demonstrated lowered numbers of peripheral blood lymphocytes and B and T cells in spleen, thymus and bone marrow as well as dose-dependent decreases in $\mathrm{CD}^{+}-\mathrm{T}$ cells, $\mathrm{CD}^{+} / \mathrm{CD}^{+}$ratio and $\mathrm{B}$ cells $[9,20,28,31]$. The observed alterations may have been linked with a hydroquinone- and catechol-induced decrease in the number of precursor cells, and damaged structure of DNA as well as ribonucleotide reductase activity [32]. Moreover, benzene metabolites may affect cytokines synthesis and their release from macrophages and, therefore, influence lymphocytes proliferation, maturation and function [10,20]. Hydroquinone inhibits the effects of TNF- $\alpha$ and, thus, of the nuclear factor $\kappa B$ (NF- $\mathrm{B}$ ), disturbing activation of both $\mathrm{T}$ and B lymphocytes. It may also inhibit production of cytokines (IL-1 $\beta$, IL-2, IL-3, IL-6, IL-10, IL-12) and inflammatory mediators $\left(\mathrm{NO}, \mathrm{PGE}_{2}\right)[10,19]$.

Qualitative evaluation of bone marrow in the benzene-exposed animals has demonstrated alterations in morphology of nucleated cells. The presence of giant granulocytes and undifferentiated cells has been probably related to benzene metabolites such as phenol and quinone, which may affect synthesis of nucleic acids through inactivation of DNA and RNA synthases or through production of free radicals, finally resulting in a disturbed structure of nucleic acids and chromosomal aberrations [6,20,33]. In the animals receiving ASA exclusively, the quality and quantity of the parameters tested in bone marrow were similar to those observed in the control animals. ASA administration to the benzene-exposed rats has resulted in a decrease in the number of giant granulocytes, which has probably reflected ASA-induced alteration in benzene biotransformation, i.e. decreased production of phenol, and inhibition of its quinone metabolite turnover in bone marrow.

Cytoenzymatic examinations have been performed to characterize functional status of granulocytes and to complete cytomorphological examinations. Peroxidases are hemoprotein enzymes occurring in neutrophils and eosinophils, starting at the promyelocyte, and their enzymatic activity increases along with the maturation of cells. There are reports that the peroxidase of macrophages of the marrow stromal may take part in oxidizing quinone metabolites of benzene and, thus, mediate its hematotoxicity $[12,34,35]$. Liberation of lipoxin A4 by ASA decreases activity of myeloperoxidase and also influences chemotaxis and stimulation of leukocytes [17,36]. Moreover, the secondary bioactivation of benzene metabolites by myeloperoxidase is inhibited by a quinone oxidoreductase present in fibroblasts of the marrow which reduces quinone biotransformation to nonreactive forms [21,37]. 
Naphthol AS-D chloroacetate esterase shows its activity only in the granulocytic cell line, mostly in monocytes. No information concerning the influence of the studied xenobiotics on activity of the enzyme is available. The observed decrease in CAE activity after ASA administration might be caused by its involvement in biochemical transformations of acetylsalicylic acid. Total influence of both studied compounds is difficult to interpret because the mechanism of inhibition of the activity of this esterase is unknown. Nevertheless, the observed changes do not seem to be beneficial for the correct maturation of granulocytic cells. Sudan Black B stains neutral lipids, phospholipids and cerebrosides present in the largest amount in the cells of the granulocytic system. Concentration of lipids increases along with maturation of the cells. In rabbits exposed to benzene vapour in subacute (14 days, $16 \mathrm{mg} / \mathrm{dm}^{3}, 6 \mathrm{~h} /$ day) and chronic (40 days, $10 \mathrm{mg} / \mathrm{dm}^{3}, 3 \mathrm{~h} /$ day) poisoning, a decrease in the lipid content in both peripheral blood granulocytes and in the bone marrow was found. In our experiment, ASA itself did not influence the content of lipids, but when administered to the rats exposed to benzene it increased the percentage of sudanophilic granulocytes, which may indicate a protective effect of the drug [38]. Cytochemical and cytoenzymatic examinations indicate benzene inhibition of granulocytic cell maturation. Simultaneous administration of acetylsalicylic acid has limited the observed changes.

In summary, our results show that higher doses of acetylsalicylic acid limited benzene induced hematotoxicity, influenced the contents of reticulocytes, neutrophilic granulocytes with structural disturbances as well as lipids level and myeloperoxidase activity.

\section{REFERENCES}

1. Snyder R. Overview of the toxicology of benzene. J Toxicol Environ Health A. 2000;61:339-46, http://dx.doi. org/10.1080/00984100050166334.
2. Ray MR, Roychoudhury S, Mukherjee S, Lahiri T. Occupational benzene exposure from vehicular sources in India and its effect on hematology, lymphocyte subsets and platelet P-selectin expression. Toxicol Ind Health. 2007;23:167-75, http://dx.doi. org/10.1177/0748233707080907.

3. Stoyanovsky DA, Goldman R, Claycamp HG, Kagan VE. Phenoxyl radical-induced thiol-dependent generation of reactive oxygen species: implications for benzene toxicity. Arch Biochem Biophys. 1995;317:315-23, http://dx.doi.org/10.1006/ abbi.1995.1169.

4. Xie Z, Zhang Y, Guliaev AB, Shen H, Hang B, Singer B, et al. The p-benzoquinone DNA adducts derived from benzene are highly mutagenic. DNA Repair (Amst). 2005;4:1399-409, http://dx.doi.org/10.1016/j.dnarep.2005.08.012.

5. Barreto G, Madureira D, Capani F, Aon-Bertolino L, Saraceno E, Alvarez-Giraldez LD. The role of catechols and free radicals in benzene toxicity: An oxidative DNA damage pathway. Environ Mol Mutagen. 2009;50:771-80, http://dx.doi. org/10.1002/em.20500.

6. Post G, Snyder R, Kalf GF. Metabolism of benzene and phenol in macrophages in vitro and the inhibition of RNA synthesis by benzene metabolites. Cell Biol Toxicol. 1986;2:231-46, http://dx.doi.org/10.1007/BF00122692.

7. King AG, Wierda D, Landreth KS. Bone marrow stromal cell regulation of B-lymphopoiesis. I. The role of macorphages, IL-1, and IL-4 in pre-B cell maturation. J Immunol. 1988;141:2016-26.

8. Renz JF, Kalf GF. Role for interleukin-1 (IL-1) in benzeneinduced hematotoxicity: inhibition of conversion of pre-IL-1 $\alpha$ to mature cytokine in murine macrophages by hydroquinone and prevention of benzene-induced hematotoxicity in mice by IL-1 $\alpha$. Blood. 1991;78:938-44.

9. Bogadi-Sare A, Zavalic M, Trosić I, Turk R, Kontosić I, Jelcić I. Study of some immunological parameters in workers occupationally exposed to benzene. Int Arch Occup Environ Health. 2000;73:397-400, http://dx.doi.org/10.1007/ s004200000126. 
10. Lee JY, Lee YG, Lee J, Yang KJ, Kim AR, Kim JY, et al. Akt Cys-310-targeted inhibition by hydroxylated benzene derivatives is tightly linked to their immunosuppressive effects. J Biol Chem. 2010;285:9932-48, http://dx.doi.org/10.1074/ jbc.M109.074872.

11. Nakajima T, Okuyama S, Yonekura I, Sato A. Effects of ethanol and phenobarbital administration on the metabolism and toxicity of benzene. Chem Biol Interact. 1985;55:23-38, http://dx.doi.org/10.1016/S0009-2797(85)80118-6.

12. Snyder R, Hedli CC. An Overview of Benzene Metabolism. Environ Health Perspect. 1996;104(Suppl. 6):1165-71, http://dx.doi.org/10.2307/3433158.

13. Verma Y, Rana SV. Modulation of CYP4502E1 and oxidative stress by testosterone in liver and kidney of benzene treated rats. Indian J Exp Biol 2008;46:568-72.

14. Damme B, Darmer D, Pankow D. Induction of hepatic cytochrome P4502E1 in rats by acetylsalicylic acid or sodium salicylate. Toxicology. 1996;106:99-103, http://dx.doi. org/10.1016/0300-483X(95)03168-F.

15. Chen XP, Tan ZR, Huang SL, Huang Z, Ou-Yang DS, Zhou HH. Isozyme-specific induction of low-dose aspirin on cytochrome P450 in healthy subjects. Clin Pharmacol Ther. 2003;73;264-71, http://dx.doi.org/10.1067/ mcp.2003.14.

16. Kowalówka-Zawieja J, Zielińska-Psuja B, Plewka A. Metabolic interactions between acetylsalicylic acid and benzene. Toxicology. 2003;188:161-70, http://dx.doi.org/10.1016/ S0300-483X(03)00082-9.

17. Morris T, Stables M, Gilroy DW. New perspectives on aspirin and the endogenous control of acute inflammatory resolution. Sci Word J. 2006;6:1048-65, http://dx.doi.org/10.1100/ tsw.2006.192.

18. Iglesias-Serret D, Piqué M, Barragán M, Cosialls AM, Santidrián AF, González-Gironès DM, et al. Aspirin induces apoptosis in human leukemia cells independently of NF-kap$\mathrm{paB}$ and MAPKs through alteration of the Mcl-1/Noxa balance. Apoptosis. 2010;15:219-29, http://dx.doi.org/10.1007/ s10495-009-0424-9.
19. Kim E, Kang BY, Kim TS. Inhibition of interleukin-12 production in mouse macrophages by hydroquinone, a reactive metabolite of benzene, via suppression of nuclear factorkappaB binding activity. Immunol Lett. 2005;99:24-9, http:// dx.doi.org/10.1016/j.imlet.2004.11.025.

20. Cho JY. Suppressive effect of hydroquinone, a benzene metabolite, on in vitro inflammatory responses mediated by macrophages, monocytes, and lymphocytes. Mediators Inflamm. 2008;2008:298010, http://dx.doi. org $/ 10.1155 / 2008 / 298010$.

21. Iskander K, Jaiswal AK. Quinone oxidoreductases in protection against myelogenous hyperplasia and benzene toxicity. Chem Biol Interact. 2005;153-154:147-57, http://dx.doi. org/10.1016/j.cbi.2005.03.019.

22. Pirozzi SJ, Schlosser MJ, Kalf GF. Prevention of benzeneinduced myelotoxicity and prostaglandin synthesis in bone marrow of mice by inhibitors of prostaglandin $\mathrm{H}$ synthase. Immunopharmacology. 1989;18:39-55, http://dx.doi. org/10.1016/0162-3109(89)90029-5.

23. Schlosser MJ, Shurina RD, Kalf GF. Prostaglandin H synthase catalyzed oxidation of hydroquinone to a sulfhydrylbinding and DNA-damaging metabolite. Chem Res Toxicol. 1990;3:333-9, http://dx.doi.org/10.1021/tx00016a010.

24. Mushtakova VM, Fomina VA, Rogovin VV. Acetylsalicylic acid as a modulator of neutrophil peroxidase system. Bull Exp Biol Med. 2009;147:708-10, http://dx.doi.org/10.1007/ s10517-009-0598-8.

25. Bala M, Chin CN, Logan AT, Amin T, Mamett LJ, Boutaud $\mathrm{O}$, et al. Acetylation of prostaglandin $\mathrm{H}_{2}$ synthases by aspirin is inhibited by redox cycling of the peroxidase. Biochem Pharmacol. 2008;75:1472-81, http://dx.doi. org/10.1016/j.bcp.2007.12.005.

26. Greer JP, Foerster J, Lukens JN, Rodgers GM, Paraskevas F, Glader B. Wintrobe's Clinical Hematology. 11th ed. Philadelphia: Lippincott Williams \& Wilkins Publisher; 2003. p. 15-35.

27. Irons RD, Lv L, Gross SA, Ye X, Bao L, Wang XQ, et al. Chronic exposure to benzene results in a unique form 
of dysplasia. Leuk Res. 2005;29:1371-80, http://dx.doi. org/10.1016/j.leukres.2005.08.019.

28. Ward CO, Kuna RA, Snyder NK, Alsaker RD, Coate WB, Craig PH. Subchronic inhalation toxicity of benzene in rats and mice. Am J Ind. Med. 1985;7:457-73, http://dx.doi. org/10.1002/ajim.4700070510.

29. Snyder CA, Goldstein BD, Sellakumar AR. The inhalation toxicology of benzene: Incidence of hematopoietic neoplasms and hepatotoxicity in ARK/J and C57BL/6J mice. Toxicol Appl Pharmacol. 1980;54:323-31, http://dx.doi. org/10.1016/0041-008X(80)90202-1.

30. Hazel BA, Baum C, Kalf GF. Hydroquinone, a bioreactive metabolite of benzene, inhibits apoptosis in myeloblasts. Stem Cells. 1996;14:730-42, http://dx.doi.org/10.1002/ stem.140730.

31. Lan Q, Zhang L, Li G, Vermeulen R, Weinberg RS, Dosemeci $\mathrm{M}$, et al. Hematotoxicity in workers exposed to low levels of benzene. Science. 2004;306:1774-6, http://dx.doi. org/10.1126/science.1102443.

32. Li Q, Kasten-Jolly J, Yen Y, Freed BM. Reversal of hydroquinone-mediated suppresion of $\mathrm{T}$ cell proliferation by transfection of the M2 subunit of ribonucleotide reductase. Toxicol Appl Pharmacol. 1998;150:154-7, http://dx.doi. org/10.1006/taap.1998.8394.

33. Yoon BI, Li GX, Kitada K, Kawasaki Y, Igarashi K, Kodama Y, et al. Mechanisms of benzene-induced hematotoxicity and leukemogenicity: cDNA microarray analyses using mouse bone marrow tissue. Environ Health Perspect. 2003;111:1411-20, http://dx.doi.org/10.1289/ txg.6164.

34. Kalf G, Shurina R, Renz J, Schlosser M. The role of hepatic metabolites of benzene in bone marrow peroxidase-mediated myelo- and genotoxicity. Adv Exp Med Biol. 1991;283: 443-55, http://dx.doi.org/10.1007/978-1-4684-5877-0_60.

35. Lévay G, Ross D, Bodell WJ. Peroxidase activation of hydroquinone results in the formation of DNA adducts in HL-60 cells, mouse bone marrow macrophages and human bone marrow. Carcinogenesis. 1993;14:2329-34, http://dx.doi. org/10.1093/carcin/14.11.2329.

36. Menezes-de-Lima Jr. O, Kassuya CA, Nascimento AF, Henriques MG, Calixto JB. Lipoxin A4 inhibits acute edema in mice: implications for the anti-edematogenic mechanism induced by aspirin. Prostaglandins Other Lipid Mediat. 2006;80:123-35, http://dx.doi.org/10.1016/j.prostaglandins.2006.05.016.

37. Bauer AK, Faiola B, Abernethy DJ, Marchan R, Pluta LJ, Wong VA, et al. Genetic susceptibility to benzene-induced toxicity: role of NADPH: quinone oxidoreductase-1. Cancer Res. 2003;63:929-35.

38. Sroczyński J, Zajusz K, Jonderko G, Węgiel A. [Effect of benzene poisoning on some cytochemical reactions in rabbit granulocytes]. Patol Pol. 1976;27:59-67. Polish.

This work is available in Open Access model and licensed under a Creative Commons Attribution-NonCommercial 3.0 Poland License - http://creativecommons.org/ licenses/by-nc/3.0/pl/deed.en. 